\title{
'I Find Myslef as Someone Who Is in the Forest': Urban Refugess as Agents of Social Change in Kampala, Uganda
}

\section{Citation}

Dryden-Peterson, Sarah. 2006. 'I find myself as someone who is in the forest': Urban refugees as agents of social change in Kampala, Uganda, Journal of Refugee Studies, 19, no. 3: 381-395

\section{Published Version}

https://doi.org/10.1093/jrs/fel010

\section{Permanent link}

http://nrs.harvard.edu/urn-3:HUL.InstRepos:40898636

\section{Terms of Use}

This article was downloaded from Harvard University's DASH repository, and is made available under the terms and conditions applicable to Other Posted Material, as set forth at http:// nrs.harvard.edu/urn-3:HUL.InstRepos:dash.current.terms-of-use\#LAA

\section{Share Your Story}

The Harvard community has made this article openly available. Please share how this access benefits you. Submit a story.

Accessibility 
'I find myself as someone who is in the forest':

Urban Refugees as Agents of Social Change in Kampala, Uganda

\author{
Sarah Dryden-Peterson \\ Harvard Graduate School of Education, Cambridge, USA \\ Refugee Law Project, Makerere University, Uganda
}

Postal Address: 397 Pforzheimer Mail Center, Cambridge, MA 02138, USA

Telephone: + 16174937841

Email: sarah_dryden@post.harvard.edu

Submitted to the Journal of Refugee Studies

As part of a special issue on Urban Refugees

November 2005

Revisions submitted: March 2006

Word Count: 6,275 


\title{
'I find myself as someone who is in the forest':
}

\author{
Urban Refugees as Agents of Social Change in Kampala, Uganda
}

\begin{abstract}
An in-depth investigation of the Kampala Urban Refugee Children's Education Centre (KURCEC), a refugee-initiated community-based organisation in Uganda, allows for detailed exploration of the livelihood strategies employed by urban refugees in the sphere of education and of the ways in which these strategies can promote self-reliance and individual and community development in urban situations. Urban refugees' development of KURCEC challenges perceived notions of refugees as burdens or as passive recipients in a system that fosters dependency and shows that they are agents of social change within their own and their host communities. The focus on what works in the midst of crisis, desperation, and uncertainty is a deliberate attempt to promote research and policy-setting that is forwardlooking and productive rather than reactionary and regressive in the context of new developments in policy and practice relating to urban refugees worldwide.
\end{abstract}

I am already dead, having lost all hope. Sometimes, I have the idea to return to my country, even if I risk getting myself killed. I would not suffer hunger, I would not sleep outside because my family is there; they could even see to my burial. I don't know what to do, what to say, or what to think.

—_Daniel,' refugee from Democratic Republic of Congo, living in Kampala, Uganda

Refugees who live in urban environments are-like Daniel—some of the world's most vulnerable citizens. ${ }^{1}$ Urban refugees are predominantly self-settled, living outside of formal assistance structures and often unable to access their rights of protection through either the United Nations High Commissioner for Refugees (UNHCR) or through host governments. Their living conditions are overcrowded and squalid; and while usually they are not poorer or better off than the citizens in whose midst they live, they persist without legal status, without support networks, and often as victims of xenophobia. Due to their ‘invisibility’ in rapidly urbanising spaces where their legal status is often undetermined, refugees in urban areas of the global South are a particularly understudied population.

The study of refugees in cities of the West is relatively well advanced, mainly because most resettled refugees and asylum seekers are to be found there. In host countries of the 
developing world, however, urban refugees are only beginning to surface in the literature on forced migration. Researchers have now studied refugees in Khartoum (Karawadi 1987; Kibreab 1996; Rogge 1985), Dar es Salaam (Sommers 2001; Willems 2003), Cairo (Briant \& Kennedy 2004; Sperl 2001), and Johannesburg (Jacobsen \& Landau 2003) and a number of advocacy groups have highlighted the vulnerability of these populations in Nairobi (Parker 2002) and in Kampala (Parker 2002; Bernstein 2005). UNHCR has also recognised trends in urbanisation of refugees and is beginning to adapt its policies to address the challenges and opportunities facing urban refugees. Yet there continues to be a paucity of research on how refugees in urban settings of the global South pursue their livelihoods, strategies that promise to inform effective policy formation. This is my point of departure in this article.

In Kampala, Uganda, refugees identify access to education as one of the most critical issues in need of attention in urban settings of displacement (Huff \& Kalyango 2002; Dryden-Peterson 2003; Bernstein 2005), and my research centres on this communityidentified priority. I employ a case study design in examining the livelihood strategies adopted by urban refugees in Kampala as they forge access to education, focusing on the Kampala Urban Refugee Children’s Education Centre (KURCEC), ${ }^{2}$ a community-based organisation that provides free primary education for refugee children.

In developing new approaches to working with urban refugees, this case provides an important example of how urban refugees can be agents of assistance and social change. Further, in choosing to focus on an example of what works, I adopt a particular stance as a researcher, one that I believe to be central in the search for durable solutions to intractable and protracted refugee 'problems.' My approach recognises that '[t]he researcher who asks first 'what is good here?' is likely to absorb a very different reality than the one who is on a mission to discover the sources of failure' (Lawrence-Lightfoot \& Davis 1997: 9). This focus does not preclude the recognition that 'goodness will always be laced with imperfections' 
(Lawrence-Lightfoot \& Davis 1997: 9). Nevertheless, I believe that a focus on what is working in the midst of the crisis, desperation, and uncertainty that Daniel describes will lead to research and policy-setting that is forward-looking and productive rather than reactionary and regressive.

The article begins with a brief analysis of international policy relating to refugees in urban areas, followed by an examination of the policy and practice of the Government of Uganda and UNHCR-Uganda and their effects on the lives of urban refugees. I then explore the development of KURCEC and its consequences for individual refugees, the urban refugee community, and the host population. Finally, I evaluate how the experience of KURCEC contributes to an understanding of the livelihoods of urban refugees and the implications of this understanding for both international and national policy.

\section{International Policy on Urban Refugees}

In 1997, UNHCR adopted a new policy related to urban refugees. This introduction followed a 1995 discussion paper that outlined main issues of concern to UNHCR in its work with refugees living in urban areas. Central among these concerns was a dilemma: '[w]hilst there is no mandate to assist, the question arises as to how broadly the organisation should interpret its mandate to protect’ (UNHCR 1995: 『2). The 1997 policy focused on establishing that, in urban areas, 'as a rule, UNHCR's assistance should be reduced to a minimum’ (Obi \& Crisp 2001: \15) in order to promote self-reliance and avoid dependency. It also conceptualised urban refugees as ‘problems’ (UNHCR 1997: ף1), whose settlement in urban areas should be discouraged. Interpreting UNHCR's mandate to protect was relegated to a secondary concern; while the document clearly stated that 'UNHCR's obligations in respect of international protection are not affected either by the location of the refugees or the 
nature of the movement to that location’ (UNHCR 1997: I2), mechanisms to enable this protection were not explored.

The 1997 policy was, in many ways, obsolete before it was made public. Drafts of the policy had been so criticised by non-governmental organisation (NGO) partners (UNHCR 1997: ๆ3) that the document was distributed with a cover letter, emphasising that the policy was a work in progress and would be revised based on comments and suggestions from UNHCR offices and partners (UNHCR 1997: \3). As a result of this uncertainty and of difficulties in execution, many stakeholders experienced a policy void related to urban refugees. In response, UNHCR's Evaluation and Policy Analysis Unit (EPAU) undertook a review of the 1997 policy and its implementation (Obi \& Crisp 2001), including the commission of case studies of selected cities (Sperl 2001; Obi \& Crisp 2000; Furley, Obi \& Crisp 2002) and further consultations with NGO partners (Obi \& Crisp 2002; ICVA 2004). On the basis of this evaluation process, the EPAU compiled a draft document, 'Protection, solutions and assistance for refugees in urban areas: Guiding principles and good practice’ (2003), in which it suggested the withdrawal of the 1997 policy and proposed its replacement with a version of these guiding principles and good practice.

The guiding principles and good practice presented in the 2003 draft document responded directly to the criticism levelled at the 1997 policy. First, the document emphasised ‘the need for a protection focus’ (EPAU 2003: 3) and outlined the particular protection threats encountered by urban refugees, including 'arbitrary arrest, detention and extortion by police and other authorities; human trafficking, especially of refugee women and girls; exploitation by employers (including child labour), traders and landlords; discrimination and physical abuse (including sexual violence) at the hands of the local population, police officers and other authorities, or by refugees themselves' (EPAU 2003: 4). Second, it called for creative approaches to the provision of assistance to urban refugees that 
could be sustained within budgetary limitations while at the same time recognising the vulnerabilities of these populations. The guiding principles supported the conclusion of an evaluation that 'a level of engagement which goes some way beyond providing the minimum level of support for the shortest possible time' (EPAU 2003: 8) was necessary. Third, the document argued that the promotion of self-reliance was critical to finding durable solutions for urban refugees. With this aim, the EPAU suggested that UNHCR might engage in selfreliance programs for urban refugees (EPAU 2003: 11-12), advocacy for national legal frameworks that allow urban refugees to exercise civil and socio-economic rights (EPAU 2003: 10-11), and support for cultural, social, recreational, sporting and refugee community activities in cities (EPAU 2003: 5).

Despite the clear recommendation of the EPAU to withdraw the 1997 policy and to replace it with a version of these guiding principles and good practice, the draft document has never been made public ${ }^{3}$ and, as yet, languishes without adoption by UNHCR. In a statement to the 2004 Executive Committee (ExCom) meeting of UNHCR, the International Council of Voluntary Agencies (ICVA) expressed concern over the failure of UNHCR to accept the draft document as policy and to move forward (IVCA 2004). Indeed, while UNHCR has recognised the inadequacies of the 1997 policy, a more effective policy has yet to supersede it.

\section{Urban Refugee Policy and Practice: The Case of Uganda}

While international policy provides a framework in which to provide protection and assistance to refugees, the policies and practices adopted by host governments are critical. Such is particularly true on the issue of urban refugees. Most governments in countries of first asylum consider displaced people living in camps or settlements to be prima facie refugees and thus to be eligible for assistance; the displaced who are living in urban areas, on 
the other hand, are often without such recognition and eligibility for assistance (Jacobsen 2004: 58). Uganda provides an example of this type of legal structure vis-à-vis refugees.

The current legislation relating to refugees in Uganda is the Control of Alien Refugees Act (CARA). ${ }^{4}$ Enacted in 1964, over a decade before Uganda ratified the 1951 Refugee Convention, the CARA is inconsistent with international standards relating to the treatment of refugees. Although the Act has never been strictly applied in Uganda (Kiapi 1998: 42; Hovil 2002: 30), the emphasis on control has nevertheless affected the realisation of civil and socio-economic rights for refugees. It regulates, for instance, the way in which assistance is delivered: Aid is contingent upon a refugee living in a designated settlement, all of which are in rural and isolated areas of Uganda. ${ }^{5}$

Despite attempts by host governments to direct the settlement of refugees to certain areas—as in the local settlement policy in Uganda—most refugees worldwide are self-settled, living dispersed amid local populations. ${ }^{6}$ According to UNHCR, in 2003, only 34 percent of refugees worldwide lived in camps, whereas 52 percent were self-settled (UNHCR 2003: 81). In Uganda, also according to UNHCR, 210,657 refugees lived in settlements; no refugees were self-settled; and 832 refugees lived in urban areas (UNHCR 2003: 79). Self-settled refugees, both rural and urban, are considered ‘aliens' by the Government of Uganda and are therefore not recognised as refugees. However, research by the Refugee Law Project (RLP) has demonstrated that, in every refugee-hosting area of Uganda, there are large numbers of self-settled displaced persons who fall under the 1951 Convention definition of 'refugee' (Kaiser, Hovil \& Lomo 2005; Hovil 2003; Bagenda, Naggaga \& Smith 2003; Werker 2002). Most of the refugees living in urban areas in Uganda are similarly self-settled. UNHCR-Uganda has a small urban caseload of 200 refugees on average each month (interview, Nasinyama 2002) who are assisted in Kampala due to security threats or medical emergencies. In addition, 10,000 refugees are registered with the Office of the Prime 
Minister (OPM) ${ }^{7}$ and the Ugandan police as 'self-sufficient refugees, ${ }^{8}$ in Kampala (Huff \& Kalyango 2002), and an estimated 5,000 to 10,000 others live in Kampala unregistered and without assistance or protection (interview, Asiimwe 2002; interview, Lomingo 2002; interview, Nasinyama 2002; Parker 2002).

Refugees are motivated to settle in urban areas for a number of reasons, including expanded employment opportunities, improved educational possibilities for themselves and their children, increased security through anonymity, and proximity to family, telecommunications, and resettlement opportunities (Kibreab 1996; Macchiavello 2003). Despite these 'pull factors,' many urban refugees in Kampala face enormous obstacles in seeking to fulfil their primary goals of acquisition of refugee status and achievement of selfsufficiency. First, the systems of application for asylum and resettlement are inefficient and confusing (Huff \& Kalyango 2002; Bernstein 2005). Many urban refugees spend each day attempting to schedule meetings with appropriate authorities and becoming cynical and frustrated with their lack of ability to move their cases forward. This bureaucracy and ambivalence of both the Government of Uganda and UNHCR cripples the agency of refugees in securing durable solutions.

Second, refugees are often unable to use their existing skills. Macchiavello (2003: 8) found that, given their education and skill level, refugees in Kampala could become selfsufficient. They are stymied, however, by lack of employment opportunities, employers’ confusion over the legality of hiring a refugee, xenophobia, and lack of ability in English. It is in this context of Ugandan policy and practice that urban refugees in Kampala forge access to education for their children. 


\section{Education of Refugees in Kampala, Uganda}

In January 1997, Universal Primary Education (UPE) was introduced in Uganda, exempting four children per family from paying primary school fees. The number of Ugandan children enrolled in primary school increased that year from 2.6 million to 5.5 million (United Nations 2000). By 1999, 6.5 million children were enrolled in primary school in Uganda, equivalent to a net enrolment rate of 85\% (United Nations 2000). The guidelines governing UPE in Kampala, however, are different than in the rest of the country; urban schools charge school fees of UShs10,400 (US\$5.60) per term (Jjuuko 2001; interview, Zirimenya-Mirumdi 2003). ${ }^{9}$

This cost makes access to the national education system in Kampala out of reach for most refugees who are not on UNHCR's urban caseload. Research by the Association des réfugies francophones (ASSOREF) concluded that 42 percent of primary school-age refugee children in Kampala were not in school. ${ }^{10}$ This lack of opportunity has obliged urban refugees to begin their own education initiatives, and refugees of different nationalities, including Somalis and Sudanese, have started self-help schools in Kampala. KURCEC is one such initiative, involving refugee children from Democratic Republic of Congo (DRC).

\section{Methods}

This case study of KURCEC is part of a multi-site, three-year longitudinal study exploring the multiple ways in which refugees access education in Uganda, including a particular focus on access in urban settings. I used multiple methods to collect data, including interviews with refugee and national community leaders $(n=10)$, district-level and educational officials $(n=8)$, and with pupils $(n=17)$ and teachers $(n=2)$ at the school. ${ }^{11}$ I engaged in classroom observations (23 lessons), often arriving unannounced, and two weeks 
of sustained participant observation at the school, with eight days of follow-up visits. Finally, I conducted a household survey that included the families of all participant pupils $(\mathrm{n}=17) .{ }^{12}$

All interviews were transcribed verbatim, and I coded them using both etic codes that emerged deductively from the literatures on urban refugees, emergency education, and refuge livelihoods and emic codes that emerged inductively from the research participants (Strauss \& Corbin 1998; Charmaz 2000). I wrote analytic memos for each of the research participants, using the etic and emic codes as organizing principles. These memos were further informed by my fieldnotes and served as a basis for several levels of comparative analysis: within the school among individual refugee pupils; within the school comparing refugee and national pupils; and over time.

\section{The Teachers: Refugees As Agents of Social Assistance}

Bauma Benjamin, 29, and Kwabo Fostin, 28, arrived in Uganda in 2000 and 1998 respectively from the Nord-Kivu province of DRC where they were trained as primary school teachers. Each taught for less than two years before fleeing from DRC. Both men spent time in refugee settlements in Uganda, but they described feeling that, as teachers, they could be 'more useful' to themselves, their families, and their communities by residing in Kampala.

Despite their short professional lives in their home country, Bauma and Kwabo exhibited a deep sense of purpose as educators. Kwabo described his calling:

When we were studying...[our teachers] gave us examples of.... if we were to arrive in the middle of a forest, where there was no education.... It is up to you, if you find yourself in that forest, to struggle to teach those children so that they will have something in their heads. And, for me, here in Kampala with these refugee children, I find myself as someone who is in the forest 
where there are children who do not know schooling.... [E]ven though there is no salary, even though there is no assistance, I still have, in my heart, this vocation. $^{13}$

This notion of personal calling and vocation surrounded the operations of KURCEC. This school was created out of necessity by two men who found children in the middle of a forest with no educational opportunities and who took it upon themselves to create something out of nothing. As individuals, they were agents of the kind of social assistance that UNHCR was not able to provide in Kampala: vocational opportunities for themselves and access to education for children.

\section{The School: The Struggle for Self-Reliance}

In creating KURCEC, Bauma and Kwabo sought to address the main educational challenge faced by refugee children: lack of free access to school. Bauma explained that '...access [to this school] is free.... [A] child is accepted without having to pay anything and without condition.’ Beginning in 2000, Bauma and Kwabo taught classes for 20 to 30 pupils in people's homes. They soon moved the classes to the Bondeko Centre, on the outskirts of Kampala, to accommodate the increasing numbers.

In 2001, authorities threatened to close this 'school' down, citing the law that prohibits a gathering of 30 children without official permission. In order to prevent this closure, the teachers began the process of obtaining a license for the school. A school without an adequate school building, however, cannot obtain a license. After much perseverance by Bauma, the school secured official permission to operate from OPM, the Kampala City Council, and the Ministry of Education and Sports. As an agent for his community, Bauma ensured that free access to education for refugee children would not cease to exist on a legal technicality. 
The lack of a permanent school building nevertheless continued to be a pressing issue for KURCEC. In February 2002, the Bondeko Centre could no longer pay for the space out of which the school operated, and Bauma sought other options. He convinced a local church to host the school, where it continued to operate through March 2004.

\section{The Pupils: Beneficiaries of Refugee Agency}

As of May 2003, 62 pupils were registered at KURCEC, and forty of them came regularly to the school. One of the pupils was from Rwanda, seven were Ugandan nationals, and the other 54 were from DRC. Eighteen of these children had ration card numbers issued by UNHCR; 12 were asylum seekers and had registered with OPM; five had been in Uganda since 1964, having originally come from DRC as refugees; and the status of 20 were undetermined.

The children lived within walking distance of the school, in an area on the outskirts of Kampala. Bauma explained the conditions in which his pupils lived: 'many of us [refugees] are very poor ... [and] pay even for food with great difficulty.' The parents of the children, most of whom completed primary school in DRC and several of whom had a few years of secondary school, had a relatively high level of education. Despite this potential advantage, all KURCEC parents had transient livelihoods within the informal economy of the city, usually selling clothes. One father described his source of income as 'divine grace' and another said that he lived 'a perilous life.'

One of the central pedagogical issues at KURCEC was language. The language of instruction in DRC is French; in Uganda, it is English. Bauma and Kwabo, in consultation with parents, decided that the language of instruction at KURCEC would be French. This would allow children to continue their education in French and would be beneficial in the 
event of repatriation to DRC. Also, without books or funds for supplies, Bauma and Kwabo could follow the curriculum from DRC, relying on their own memories of the content.

While intended to serve refugees, KURCEC also met the needs of poor Ugandans. 'I come here because my father has no money,' one national child explained. In this way, the social assistance expanded beyond the urban refugee population of Kampala and to the host community. Kwabo explained:

In this school, to obtain access to education, there is not the condition that you must be a refugee. Instead, this school is for all the people who do not have the means to pay for their studies in local schools here. Even if you are Ugandan...you always have the right to come to school here.

That Ugandan nationals would choose to attend KURCEC underlines the limited access to primary education in Kampala. Even though the language of instruction at KURCEC was French—a language new to Ugandan children and arguably not useful for them—some parents felt that KURCEC would provide a better and more stable education than local UPE schools. In UPE schools in Kampala, there may be up to 200 pupils in one class, and pupils do not receive the attention they need to succeed in their studies. ${ }^{14}$

Despite a lack of resources, the teachers at KURCEC gave pupils abundant and high quality individual attention. The low pupil to teacher ratio allowed for extensive interaction between pupils and teachers, frequent marking of books, and class participation by all pupils. For example, by 11 on a given morning, Kwabo had checked each of his pupil’s notebooks three times; by contrast, in UPE classrooms, pupils often go days without any individual attention from teachers. One refugee child told me excitedly: 'I'm learning everything [at this school]!'

The Refugee Community: Refugees As Agents of Social Change 
The innovative quality of KURCEC goes beyond its unique provision of education to refugee children in Kampala. The process by which KURCEC came about reflects the dynamic coping strategies adopted by the refugees involved. The development of KURCEC required overcoming a variety of structural constraints in the form of limitations placed on urban refugees by UNHCR and the Government of Uganda. Further, for Bauma and Kwabo, starting the school was not for personal benefit, despite the fact that they struggled to support themselves. Bauma, a husband and father of two, received a small microcredit loan from Caritas with which he bought Bitenge cloth and sold it during non-school hours; Kwabo, still single, lived with his parents who had also come to Kampala from DRC. For their work at KURCEC, they did not receive any monetary compensation. Rather, they sought to provide a service to the refugee community. What the two men got out of their work at the school related to their need for fulfilment and a sense of accomplishment, needs that are pursued in refugees’ coping strategies as much as economic self-sufficiency.

The agency exhibited by Bauma and Kwabo in the development of KURCEC derived in part from their beliefs about individual responsibility, as well as their abilities to negotiate a system that is premised on the restriction of refugee livelihoods in urban areas. Their vocation for teaching led them to respond to a community need for education of refugee children; and their sense of responsibility to this refugee community urged them to teach its children voluntarily despite the difficulties posed for their individual self-sufficiency. Most importantly for the exile context in which they lived, Bauma and Kwabo were able to deal with Ugandan authorities in non-threatening ways, particularly through earnest attempts to comply with Ugandan law in all its vagaries and to acquire the correct paperwork for the operation of their school. In addition, KURCEC gained the respect of the local community by providing a tangible benefit of free education to children in the host community. 
The process by which agency was employed by individual refugees contributed to social change for the individual refugees involved — both adults and children — and for the greater urban refugee community. Each day, Bauma said, he sought to ensure that 'refugee children benefit, just like other children, from education.’ The initiative taken by Bauma and Kwabo to create KURCEC allowed them to feel productive as individuals and useful to their community, despite their liminal status as urban refugees. Parents of pupils at KURCEC reported that their children were happier having a place to go to school; 'this school creates stability for my sons, and they are learning,' said one father. The success of KURCEC is proof of the assets refugees bring to their urban situations, including to their hosts.

\section{Toward Policy That Facilitates the Agency of Urban Refugees}

Started in 2001, KURCEC operated without interruption for three years through the commitment of a small group of volunteer refugee teachers. In March 2004, the school was evicted from the church in which it operated due to pressure on the Pastor from several parishioners who were suspicious of the activities of 'foreigners.' Up to May 2005, no classes were held. The teachers saw this closure as temporary and continued to work tirelessly to find a new site for their school. In April 2004, a wealthy Ugandan donor attempted to give the school land on which to construct its own permanent building. According to Ugandan law, however, refugees cannot own land, and the process of transferring the land and beginning construction of the school has been held up with lawyers and city officials since that time. ${ }^{15}$

This disruption had a number of consequences for the pupils of KURCEC, their families, and the education of refugee children in Kampala. These consequences, outlined below, only serve to underscore the critical gap that this refugee-initiated organisation filled 
in Kampala and the need for international and national policy and practice to facilitate these types of initiatives in urban areas.

The suspension of classes at KURCEC meant that access to education for refugees from DRC in Kampala became limited. While all of the national pupils who previously attended KURCEC enrolled in other local primary schools, two of the seven refugee research participants who remained in Kampala were not in school. ${ }^{16}$ The dispositions of these two children visibly changed; while they once exuded curiosity, the two boys developed vacant eyes and resigned attitudes. In my fieldnotes, I wrote:

'Samuel' sits on the row of grass by the side of the house and just watches the world. Judging from observations of him in class [last year], I never would have guessed he could sit still for so long. He doesn't seem to be doing anything. He seems to have lost all passion.

Four months later, Samuel explained that what makes him most sad 'is to see my friends go to school in the morning, but not me. I have decided to wake up every day at 9 o'clock to avoid seeing these other children who are able to go to school.' For Samuel, a sense of hope for the future all but disappeared with the closing of KURCEC. In addition, the situation of the refugee children who were able to persist in school became precarious, with children repeatedly chased away from their local government-aided and private schools for failure to pay school fees. Between July and November 2004, five refugee children from KURCEC who had transferred to another school when KURCEC closed were forced to miss at least ten days of school for failure to pay school fees, and two disrupted their studies by changing schools yet again in order to avoid being kicked out of school completely.

Acknowledgment and understanding of both the presence of refugees in urban areas and their contributions to refugee and host communities are necessary guides to future policy formation by UNHCR and host governments. Indeed, if the purpose of refugee policy is to 
promote the protection, assistance, and self-reliance of refugees, then UNHCR should engage with individuals and groups such as those involved with KURCEC. In seeking out examples of what works, possibilities for policy and practice in difficult situations reveal themselves. As the KURCEC initiative demonstrates, refugees often serve as their own agents in Kampala, creating community structures that support self-reliance. Yet as the current struggles of KURCEC reveal, there are limitations to what individual refugees can do within a legal structure that does not recognise the rights of refugees. Without any institutional support, large numbers of refugee children remain without access to education in Kampala, outside of the reach of a small organisation like KURCEC.

The opportunity is ripe for UNHCR and host governments to work together to facilitate—structurally and institutionally, but not necessarily financially—-the continued existence of successful refugee-initiated institutions. That is perhaps the most important and sustainable role these larger entities can play. In UNHCR advocacy to host governments for the rights of refugees, initiatives like KURCEC might be used as examples that can generate the political will necessary for productive outcomes. Indeed, the refugees involved with the development of the Kampala Urban Refugee Children’s Education Centre have challenged perceived notions of themselves as burdens or as mere actors within a system that fosters dependency. They present themselves as agents of social assistance and social change within their own and their host communities. If structures to help facilitate this kind of initiative were in place and effectively maintained, refugees would become social and economic assets to cities of the global South. 


\section{References}

BAGENDA, E., NAGGAGA, A., and SMITH E. (2003) 'Land Problems in Nakivale Settlement and the Implications for Refugee Protection in Uganda.' Kampala: Refugee Law Project Working Paper No. 8.

BAKEWELL, O. (2000) 'Repatriation and self-settled refugees in Zambia: bringing solutions to the wrong problems.' Journal of Refugee Studies. 13(4): 356-373.

BERNSTEIN, J. (2005) “'A Drop in the Ocean’: Assistance and Protection for Forced Migrants in Kampala.’ Kampala: Refugee Law Project Working Paper No. 16.

BLACK, R. (1998) 'Putting Refugees in Camps.' Forced Migration Review. 4: 4-7.

BRIANT, N. and KENNEDY, A. (2004) 'An Investigation of the Perceived Needs and Priorities Held By African Refugees in an Urban Setting in a First Country of Asylum,' Journal of Refugee Studies, 17(4): 437-459.

CHARMAZ, K. (2000) 'Grounded Theory: Objectivist and Constructivist Models.'

In Norma K. Denzin and Yvonna S. Lincoln (Eds). Handbook of Qualitative Research, $2^{\text {nd }}$ edition. Thousand Oaks, California: Sage Publications, pp.509-535. DEININGER, K. (2003) 'Does cost of schooling affect enrollment by the poor? Universal primary education in Uganda.' Economics of Education Review. 22(2003): 291-305.

DRYDEN-PETERSON, S. (2003) 'Education of Refugees in Uganda: Relationships

Between Setting and Access.’ Kampala: Refugee Law Project Working Paper No. 9.

DRYDEN-PETERSON, S. (under review) 'Academic Research and the Search for Durable Solutions: Possibilities in Research Design.’ In Greta Uehling (Ed.), Research Methods in Humanitarian Contexts.

DRYDEN-PETERSON, S. and HOVIL, L. (2004) 'Local Integration of Refugees and Their Hosts in the Case of Uganda.' Refuge. 22(1): 26-28. 
EVALUATION AND POLICY ANALYSIS UNIT (EPAU). (2003) 'Protection, solutions and assistance for refugees in urban areas: Guiding principles and good practice, draft.' Geneva: UNHCR Evaluation and Policy Analysis Unit.

FURLEY, K., OBI, N. and CRISP, J. (2002) 'Evaluation of UNHCR’s policy on refugees in urban areas: Report of a workshop, Moscow, March 2002.’ Geneva: UNHCR Evaluation and Policy Analysis Unit.

GLOBAL IDP PROJECT. (2005). 'Profile of Internal Displacement: Uganda.' (www.idpproject.org)

HOVIL, L. (2002) 'Free to Stay, Free to Go? Movement, Seclusion and Integration of Refugees in Moyo District.’ Kampala: Refugee Law Project Working Paper No. 4. HOVIL, L. (2003) 'Displacement in Bundibugyo District: A Situational Analysis.' Kampala: Refugee Law Project Working Paper No. 10.

HOVIL, L. and LOMO, Z. (2004) 'Behind the Violence: Causes, Consequences and the Search for Solutions to the War in Northern Uganda.' Kampala: Refugee Law Project Working Paper No. 11.

HOVIL, L. and MOREHEAD, A. (2002) 'War as Normal; The Impact of Violence on the Lives of Displaced Communities in Pader District, Northern Uganda.' Kampala: Refugee Law Project Working Paper No. 5.

HUFF, K. and R. KALYANGO. (2002) 'Refugees in the City: Status Determination, Resettlement and the Changing Nature of Forced Migration in Uganda.’ Kampala: Refugee Law Project Working Paper No. 6.

HUMAN RIGHTS WATCH. (2003) 'Abducted and Abused: Renewed Conflict in Northern Uganda.' Vol. 15, No. 12 (A), July 2003.

INTERNATIONAL COUNCIL OF VOLUNTARY AGENCIES. (2004) 'Evaluation and Inspection Activities NGO Submission Agenda Item 7.' Statement presented at the 
$55^{\text {th }}$ Session of the UNHCR Executive Committee of the High Commissioner's

Programme, Geneva, 4-8 October, 2004.

INTERNATIONAL CRISIS GROUP. (2004) 'Northern Uganda: Understanding and Solving the Conflict.’ IGC Africa Report No. 77, April 2004.

JACOBSEN, K. (2004) 'Just Enough for the City: Urban refugees Make their Own Way.' World Refugee Survey, 2004. Washington: U.S. Committee for Refugees.

JACOBSEN, K. and LANDAU, L. (2003) 'The Dual Imperative in Refugee Research: Some Methodological and Ethical Considerations in Social Science Research on Forced Migration.’ Disasters 27(3):185-206.

JJUUKO, E.C. (3 December 2001) “UPE numbers in the city soar to 190,000.” The Monitor. Kampala.

KAISER, T. (2002) 'UNHCR’s withdrawal from Kiryandongo: anatomy of a handover.' Refugee Survey Quarterly. 21(1). pp.201-227.

KAISER, T., HOVIL, L and LOMO, Z. (2005) “'We are Stranded Here Together”: Freedom of Movement, Settlements, and Self-Settled Refugees in Arua and Moyo District.’ Kampala: Refugee Law Project Working Paper No. 14.

KARAWADI, A. (1987) 'The Problem of Urban Refugees in Sudan,’ in J. Rogge (ed), Refugees: A Third World Dilemma, pp.115-129. Toronto: Rowman and Littlefield.

KIAPI, A. (1998) 'The Legal Status of Refugees in Uganda: A Critical Study of Legislative Instruments,' in Gingyera Pinycwa, A.G.G. (ed) Uganda and the Problem of Refugees. Kampala: Makerere University Press.

KIBREAB, G. (1996) 'Eritrean and Ethiopian Urban Refugees in Khartoum: What the Eye Refuses to See.’ African Studies Review 39(3): 131-178.

LANDAU, L. (2004) 'FMO Research Guide: Urban Refugees.' Forced Migration Online (www.forcedmigration.org). 
LAWRENCE-LIGHTFOOT, S. and J. DAVIS. (1997) The Art and Science of

Portraiture. San Francisco: Jossey-Bass.

MACCHIAVELLO, M. (2003) 'Forced migrants as an under-utilized asset: refugee skills, livelihoods, and achievements in Kampala, Uganda.' New Issues in Refugee Research, Working Paper No. 95, Geneva: UNHCR.

MALKKI, L. (1995) Purity and Exile: Violence, Memory and National Cosmology Among Hutu Refugees in Tanzania. London: University of Chicago Press.

\section{MINISTRY OF FINANCE, PLANNING AND ECONOMIC DEVELOPMENT}

(MFPED). (2001) Poverty Eradication Action Plan (2001-2003)[Volume 1]. Kampala: MFPED.

OBI, N. and CRISP, J. (2000) “Evaluation of UNHCR’s policy on refugees in urban areas: a case study review of New Delhi.' Geneva: UNHCR Evaluation and Policy Analysis Unit.

OBI, N. and CRISP, J. (2001) 'Evaluation of the implementation of UNHCR's policy on refugees in urban areas.’ Geneva: UNHCR Evaluation and Policy Analysis Unit.

OBI, N. and CRISP, J. (2002) 'UNHCR policy on refugees in urban areas: Report of a UNHCR/NGO workshop.’ Geneva: UNHCR Evaluation and Policy Analysis Unit.

OFFICE OF THE PRIME MINISTER/UNHCR UGANDA. (1999) 'Strategy Paper: Self Reliance for Refugee Hosting Areas in Moyo, Arua, and Adjumani Districts, 19992005.'

PARKER, A. (2002) 'Hidden in Plain View: Refugees Living Without Protection in Nairobi and Kampala.’ New York: Human Rights Watch.

PRATHER, C.J. (2004) 'Reaching for the Sky: Uganda’s Quest for Universal Primary Education.' Washington: Creative Associates International, Inc. 
ROGGE, J.R. (1987) 'Urban Refugees in Africa: Some Changing Dimensions to Africa’s Refugee Problem, with Special Reference to the Sudan.’ Migration World XIV (4): 7-13. SOMMERS, M. (2001) 'Young, Male and Pentecostal: Urban Refugees in Dar es Salaam, Tanzania.' Journal of Refugee Studies 14(4): 347-370.

SPERL, S. (2001) 'Evaluation of UNHCR's policy on refugees in urban areas: a case study review of Cairo.' Geneva: UNHCR Evaluation and Policy Analysis Unit.

STRAUSS, A. and J. CORBIN. 1998. Basics of Qualitative Research: Techniques and Procedures for Developing Grounded Theory. Thousand Oaks, California: Sage Publications.

UNHCR. (1995) 'UNHCR’s Policy and Practice Regarding Urban Refugees, A Discussion Paper.' Geneva: UNHCR.

UNHCR. (1997) 'UNHCR Policy on refugees in urban areas.' Geneva: UNHCR.

UNHCR. (2003) '2003 Global Refugee Trends: Overview of Refugee Populations, New Arrivals, Durable Solutions, Asylum-seekers and Other Persons of Concern to UNHCR.' Geneva: Population Data Unit, UNHCR.

UNITED NATIONS. (2000) Uganda: Promise, Performance and Future Challenges (Common Country Assessment of the United Nations agencies working in Uganda). Kampala: The United Nations System in Uganda.

WERKER, E. (2002) 'Refugees in Kyangwali Settlement: Constraints on Economic Freedoms.’ Kampala: Refugee Law Project Working Paper No. 7.

WILLEMS, R. (2003) 'The Refugee Experience: Forced Migration and Social Networks in Dar es Salaam, Tanzania.’ Ph.D. dissertation (anthropology), University of Florida.

\section{Interviews}

NASINYAMA, S. (2002) Executive Director, Inter-Aid, Kampala (18 November). 
ASIIMWE, D. (2002) Senior Protection Officer, Office of the Prime Minister, Kampala (4 November).

LOMINGO, E. (2002) Director, Congolese Refugee Development Association (COREDA), Kampala (19 November).

ZIRIMENYA-MIRUMDI, J. (2003) Headmaster, Katwe Primary School, Kampala (19 March).

Please note that interviews with teachers, children and their parents are not cited in order to protect their identities.

\section{Notes}

${ }^{1}$ This article is a revised version of a paper presented under the same title at the International Association for the Study of Forced Migration meetings in Sao Paulo, Brazil, 9-13 January 2005 and at the Social Science Research Council Summer Institute on Migration at University of California Irvine, 27-30 June 2005. I would like to thank the Mellon Foundation, the Migration and Urbanisation Node of the University of the Witwatersrand, and the Fulbright Commission for their generous support of my larger project on refugee education, out of which this work on refugees in urban areas comes.

2 The name of the Kampala Urban Refugee Children’s Education Centre has not been changed in order to respect the wishes of the adults who work with this organisation. The names of all teachers, parents, pupils, and community members have been changed to protect their identities.

${ }^{3}$ A copy of this document is held by the author.

${ }^{4}$ A new refugee bill was introduced by the Office of the Prime Minister (OPM) in 2003, however, it has yet to be passed by the Ugandan parliament. The draft version of this new bill respects the right to freedom of movement for refugees, but the bill also notes that freedom of movement is subject to 'directions issued by the Commissioner’ (\$30).

${ }^{5}$ This local settlement policy was designed to promote a degree of self-sufficiency for refugees, specifically through the provision of land (OPM/UNHCR, 1999: 12). However, the lack of sufficient arable land; the general insecurity that has, for decades, characterised the areas of northern Uganda in which the majority of 
settlements are located (Global IDP Project, 2005; Hovil \& Morehead, 2002; Human Rights Watch, 2003; International Crisis Group, 2004; Lomo \& Hovil, 2004); and the restrictions imposed on movement, which promote economic isolation and social seclusion, have compromised attempts at self-sufficiency in most cases (Kaiser, 2002; Werker, 2002; Hovil, 2002; Dryden-Peterson \& Hovil, 2004).

${ }^{6}$ For detailed discussions on the processes and experiences of refugee self-settlement, see Bakewell, 2000; Black, 1998; Kaiser, Hovil \& Lomo, 2005; and Malkki, 1995.

${ }^{7}$ The Office of the Prime Minister, Directorate of Refugees, is the Ugandan government structure under which responsibility for refugees falls.

${ }^{8}$ OPM provides refugees with official papers permitting them to live in Kampala if they can prove 'selfsufficiency’ by way of a letter from an employer or evidence of residency. This policy does not exist on paper (Bernstein, 2005) but has been in practice since at least 2002.

${ }^{9}$ For further discussion of UPE in Uganda, see Prather, 2004; and Deininger, 2003.

${ }^{10}$ Copies of this data, collected by the refugee organisation ASSOREF, are held by the author.

${ }^{11}$ At KURCEC, I interviewed a total of seventeen children, ten refugees and seven nationals (the total number of nationals in the school), and all of the teachers who taught these pupils.

${ }^{12}$ See Dryden-Peterson (under review) for a detailed explanation of the research design and methods of this study.

${ }^{13}$ All quotes from teachers, pupils, parents, officials, and community leaders come from interviews conducted in 2002 and 2003.

14 See MFPED 2001: 24: 'Internationally, class size has not been found to be very powerful in explaining learning outcomes, but very few countries have class sizes as large as Uganda's now; the evidence in Uganda is that class size does make a difference.’

${ }^{15}$ During the last half of 2005, KURCEC initiated a partnership with a local Ugandan school in an attempt to secure access to education for a few refugee pupils. Refugee pupils were asked to contribute a small sum of money with national parents subsidising most of the costs of running the school. While KURCEC has, of necessity, begun to charge these small school fees and the long-term stability of this new initiative is uncertain, the partnership has continued into the 2006 school year.

${ }^{16}$ In addition, two research participants have been resettled to the United States and one has been resettled to Canada. 